\title{
Paideusis
}

\section{Of Human Potential: An Essay in the Philosophy of Education (Israel Scheffler)}

Deborah Court

Volume 3, Number 1, 1989

URI: https://id.erudit.org/iderudit/1073408ar

DOI: https://doi.org/10.7202/1073408ar

See table of contents

Publisher(s)

Canadian Philosophy of Education Society

ISSN

0838-4517 (print)

1916-0348 (digital)

Explore this journal

Cite this review

Court, D. (1989). Review of [Of Human Potential: An Essay in the Philosophy of Education (Israel Scheffler)]. Paideusis, 3(1), 23-25.

https://doi.org/10.7202/1073408ar viewed online.

https://apropos.erudit.org/en/users/policy-on-use/ 
This book is the second in a series of four to arise out of the Project on Human Potential at the Harvard Graduate School of Education. Following a request from the Bernard van Leer Foundation in the Netherlands, an international non-profit institute working to better the lot of disadvantaged children, a group of scholars at Harvard set to explore the nature and realization of human potential. The first of the Project's four books looks at the psychological nature of potential; the second--Scheffler's book--takes a philosophical view; the third is anthropological and the fourth, a cross-cultural study, looks at non-Western notions of potential. The aim of the Project is not to construct a scientific theory of potential, but, through interdisciplinary investigations, to develop a practical theory useful for guiding decisions in some realm of practice. Scheffler claims, sensibly it would seem, that "the language of potential finds its natural home not in current social science but in educational practice." Thus, the work of the Project is largely directed toward "a practical theory of educational decisionmaking."

Scheffler's contribution offers no ultimate answers but some useful clarification, and succeeds in getting readers to reflect on some of the mistaken taken-for-granteds in education. A dogged and systematic philosophical analysis of potential forms the heart of the volume. The book is divided into four sections. The first examines and criticizes some existing notions of potential. The second offers three reconstructions of the language of potential. The third suggests empirical applications of the conceptual framework thus developed, and the fourth discusses implications for educational policy and the education of policy makers.

What is perhaps one of the single most important points in the book seems at first glance so obvious as to be almost trite. "Teachers, examiners and counselors," writes Scheffler, "strive to assess students' potentials. Attributing the possession of given potentials to some, they deny it to others." Considerable power to shape students' lives lies in the decisions of teachers, examiners, and counselors, and their arguments are often couched in the magic language of potential. "He's got it and she hasn't." "You've got this potential and she's got that one." "He appears to have little potential at all." As a public school teacher who was no doubt also guilty of making such assumptions, I was nevertheless horrified when a learning assistance teacher informed me, in response to my request for help in planning a program for one of my lowest students, that the best this boy could hope for in life was "to learn how to make change." She had "read" his potential from his school performance, from test results, and from his family background, and as far as she was concerned his destiny was determined: he was a loser. This "myth of fixed potentials" is the first of three "myths" Scheffler identifies.

A second important point revolves around the "myth of harmonious potentials" according to which educators need only identify students' potentials and then promote their realization. All potentials are assumed to be harmoniously realisable. No value choices need be made; the problem is reduced to a question of fact (What potentials does the student have?) and a question of technology (How are these potentials most efficiently to be realized?). Scheffler 
argues that many potentials are not jointly realizable, and that choices between various paths must be made. On what basis are such choices to be made? Potentials are not equally desirable; people are potentially evil as well as good. A student may have the potential to become a criminal or drug addict as well as a mathematician or musician. Thus, Scheffler exposes the "myth of uniformly valuable potentials."

That the directions in which educators encourage and do not encourage students involve normative decisions, and that the choices students make for themselves are choices based on standards of value, seems, again, so obvious as scarcely to need mention, but it is a central point, and it is probably true that most of us seldom question the values which guide us. Scheffler urges that a critical eye be directed to our social norms, because individuals' choices are both born of and change their social norms. Scheffler calls upon the moral vision of Kant to guide educational decision making. Paramount in such a vision--updated to include our present day knowledge of cross-cultural variations--would be human dignity, respect for persons, and equal opportunity to develop desirable potentials.

Having exposed the "myths" about potential and made clear the normative outlook of the Project, Scheffler proceeds to a philosophical and conceptual analysis of potential. He traces the three "myths" back to Aristotle's metaphysic of essences defining natural kinds. The acorn, a potential oak, need only realize and move toward its natural end. People are destined for certain ends, some to be scholars and some slaves, and it is natural and right for them to realize this innate potential. This has been a surprisingly tenacious notion in education, and even once it has been debunked we are left with some difficult questions. How are we to say what a child's intrinsic potentials are? And if we can identify these, how are we to say which are valuable and should be encouraged? And is realization of potential a straight line from " $a$ "to " $b$ ", or do diverse developmental factors come into play?

In his analysis, Scheffler sets forth three reconstructed concepts of potential, a capacity notion, a propensity notion, and a capability notion. Potential as a capacity may be understood in the following way. Someone with a capacity to develop a certain trait is one whose acquisition of the feature is not blocked by a preventive circumstance such as, say, a nutritional deficiency or a disease. Potential as propensity sets up a conditional prediction of an "if-then" form. If a certain (more or less vague) set of conditions holds, then this person is likely to develop that potential. Scheffler uses the example of a potential heart attack victim, whose medical history and lifestyle seem to be leading to a particular end. We may also speak of a child as a potential soccer star, and imagine what the conditions might be for fulfilling this potential. Potential as a capability to become also sets up a conditional "if-then" prediction, with the "if' becoming the agent's own choice. A person will likely realize this potential if he or she chooses to do whatever is necessary for that realization. Here the development of potential becomes self-development.

The three notions are, as Scheffler points out, compatible. In education, they can be seen as the enabling of learning, the development of learning, and the self-development or empowering of learning. Children do not always know their own powers, and educators need to give them opportunity and reinforcement. "The thrill of new mastery," writes Scheffler, "often springs from the 
confirmation of potential the child did not believe it had. Often too, such mastery is facilitated by the teacher's display of faith in the student's potential, which overcomes the student's groundless skepticism."

Running throughout the first two sections of the book are many examples of how potentials are attributed or denied to children in schools. In the third section, devoted to possible real world applications of the conceptual framework he has developed, Scheffler expands the field to include the notion of potential as it is used in international development. He claims that the international development community has in the past considered each "pre-modern" country to be a potential "modern" one, each non-industrial society a potential industrial one. This demonstrates what Scheffler has called the propensity notion: "if only certain features were instituted, then ..." The danger in this outlook is the presumption that the developer's values, knowledge and worldview are the critical ones. Scheffler argues for a capability notion of potential in international development, emphasizing self-development and the empowering of people in other countries to make their own choices. He also argues for extensive cross-cultural studies to expand our notions of potential (what we see as impediments others might not, for instance) and to help us to decide what beliefs and values to adopt.

In the last section of the book Scheffler discusses policy-making and the education of policy makers, and says that as well as multidisciplinary, crosscultural, conceptual, and value issues, policy makers need to address temporal issues, seeing policy decisions as part of a historical continuity. By this, he means that policy makers, while making decisions in the present, for the future, must check the consequences of past decisions. He argues for a combination of resolute present action with critical scrutiny of past decisions. Actions should be examined not only for their effectiveness but for "a sense of the normative space they help to form." The policy maker in this vision is a person, not a faceless entity of authority, a person who reflects on "not only what we have done to transform the problem, but how our deeds have transformed ourselves."

The book is beautifully written, offering clarity and precision of analysis and, in Scheffler's vision of a world of reflective, self-critical men and women, something of the quality of poetry. It is an ambitious book, mapping the meanings and possibilities of potential and applying the understanding gained through this work to education and to international development. Both of these applications are important and the work is insightfully done, but there is something of a disjuncture in the combination. One might have wished that more pages be devoted to education, and that a separate book take up the investigations as they apply to the related, but somewhat different field of international development. Nevertheless, the book is recommended for its new insights as well as its careful reminders of the oft-forgotten obvious.

Deborah Court, University of Victoria 